\title{
PENGARUH VARIABEL MAKROEKONOMI TERHADAP DANA PIHAK KETIGA BANK UMUM SYARIAH DI INDONESIA
}

\author{
Muhammad Dzulfaqori Jatnika \\ Program Studi Magister Sains Ekonomi Islam, Universitas Airlangga \\ Email : muhammad.dzulfaqori,jatnika-2018@pasca.unair.ac.id
}

Masuk : 04-02-2020, revisi: 30-04-2020, diterima untuk diterbitkan : 30-04-2020

\begin{abstract}
ABSTRAK
Tujuan penelitian ini adalah menganalisis pengaruh faktor makroekonomi yaitu nilai tukar, inflasi, suku bunga, dan GDP per kapita terhadap dana pihak ketiga di bank umum Syariah. Penelitian ini merupakan penelitian kuantitatif dengan data sekunder yang berupa data panel. Teknik analisis yang digunakan adalah metode analisis linier berganda Ordinary Least Square (OLS). Hasil uji Hausman menunjukan model yang tepat dalam penelitian ini adalah random effect model. Semua variabel signifikan, variabel inflasi dan nilai tukar memiliki pengaruh positif sedangkan variabel suku bunga dan GDP per kapita memiliki pengaruh yang negatif terhadap dana pihak ketiga di bank umum Syariah. Hasil penelitian ini memiliki implikasi bagi para pelaku usaha perbankan untuk menentukan waktu yang tepat dalam menarik dan menyalurkan dana pihak ketiga dari masyarakat. Dan dapat menjadi acuan untuk mengeluarkan kebijakan terkait bisnisnya. Dan bagi peneliti selanjutnya dapat menjadi acuan untuk mengembangkan kembali penelitian berikutnya. Pada penelitian selanjutnya diharapkan dapat menambah variabelvariabel terkait lainnya selain variabel yang telah diteliti dalam penelitian ini. Kebaruan dalam penelitian ini adalah tambahan variabel yang mempengaruhi dana pihak ketiga dan juga tambahan sampel bank umum Syariah sehingga diharapkan penelitian ini lebih mendalam daripada penelitian sebelumnya.
\end{abstract}

Kata Kunci : Makroekonomi, Dana Pihak Ketiga, OLS.

\begin{abstract}
The purpose of this study is to analyze the influence of macroeconomic factors, namely the exchange rate, inflation, interest rates, and GDP per capita on third party funds in Islamic commercial banks. This research is a quantitative study with secondary data in the form of panel data. The analysis technique used is the Ordinary Least Square $(O L S)$ multiple linear analysis method. The Hausman test results showed the right model in this study was the random effect model. All variables are significant, inflation and exchange rates have a positive effect while interest rates and GDP per capita have a negative effect on third-party funds in Islamic commercial banks. The results of this study have implications for banking businesses to determine the right time in attracting and channelling third party funds from the public. And can be a reference for issuing policies related to business. And for further researchers can be a reference to develop further research. In the next research, it is expected to be able to add other related variables besides the variables that have been examined in this study. The novelty in this study is the addition of variables that affect third party funds and also additional samples of Islamic commercial banks so that this research is expected to be more in-depth than previous research.
\end{abstract}

Keywords : Macroeconomics, Third Party Fund, OLS.

\section{PENDAHULUAN}

Adanya perbankan secara umum memiliki fungsi strategi sebagai lembaga intermediasi dan memberikan jasa dalam lalu lintas pembayaran seperti penyerapan dan juga penyaluran dana dari masyarakat. Namun, pengaruh kondisi perekonomian di Indonesia baik variabel ekonomi makro maupun variabel moneter yang perkembangannya dapat dikendalikan oleh bank sentral juga memiliki andil dalam penyerapan dana masyarakat yang dilakukan oleh perbankan. Fungsi intermediasi perbankan juga dipengaruhi oleh kondisi ekonomi makro diantaranya, tingkat bunga, inflasi, dan fluktuasi nilai tukar. Faktor inflasi mencerminkan stabilitas ekonomi, jika tingkat inflasi meningkat, masyarakat cenderung mengurangi saving/investasi. Maka aset perbankan secara riil akan menurun, sehingga akan mempengaruhi kemampuan operasi perbankan dalam penyaluran kredit (Haryati, 2009). 
Pertumbuhan setiap bank sangat dipengaruhi oleh perkembangan kemampuannya menghimpun dana masyarakat. Sebagai lembaga keuangan, maka dana merupakan masalah bank yang paling utama. Tanpa dana yang cukup, bank tidak dapat berbuat apa-apa atau dengan kata lain, bank menjadi tidak berfungsi sama sekali (Danupranata, 2013).

Bank berperan sangat penting untuk mendorong pertumbuhan perekonomian suatu negara karena bank adalah pengumpul dana dari masyarakat yang kelebihan dana dan penyalur kredit kepada masyarakat yang kekurangan dana (Hasibuan, 2011). Bank sebagai lembaga keuangan memberikan kontribusi yang besar dalam peningkatan PDB di Indonesia. Dana atau uang tunai yang dimiliki oleh bank tidak hanya berasal dari modal pemilik bank itu sendiri maupun pinjaman dari pihak lain seperti pinjaman antar bank, akan tetapi juga berasal dari simpanan masyarakat atau dikenal dengan DPK yang bisa berupa tabungan, giro, dan deposito.

Dana pihak ketiga adalah "dana yang berasal dari masyarakat, baik perorangan maupun badan usaha, yang diperoleh bank dengan menggunakan berbagai instrumen produk simpanan yang dimiliki oleh bank (Kuncoro, 2002). Menurut Rivai dalam Umiyati dan Leni (2017) Dana Pihak Ketiga adalah dana yang diperoleh dari masyarakat, dalam arti masyarakat sebagai individu, perusahaan, pemerintah, rumah tangga, koperasi, yayasan, dan lain-lain baik dalam mata uang rupiah maupun dalam valuta asing. Pada sebagian besar atau setiap bank, dana masyarakat ini umumnya merupakan dana terbesar yang dimiliki. Hal ini sesuai dengan fungsi bank sebagai penghimpun dana dari masyarakat.

Tabel 1 Data Variabel Makroekonomi dan Dana Pihak Ketiga 2016-2019

Sumber : Data diolah

\begin{tabular}{|c|c|c|c|c|c|}
\hline Tahun & $\begin{array}{l}\text { Inflasi } \\
(\%)\end{array}$ & $\begin{array}{l}\text { GDP per } \\
\text { kapita } \\
\text { (Dollar) }\end{array}$ & $\begin{array}{l}\text { Nilai } \\
\text { Tukar } \\
\text { (Rupiah) }\end{array}$ & $\begin{array}{l}\text { Suku } \\
\text { Bunga (\%) }\end{array}$ & $\begin{array}{l}\text { Dana Pihak Ketiga Bank } \\
\text { Syariah (dalam miliar rupiah) }\end{array}$ \\
\hline 2015 & 3,35 & 3332 & 13795 & 7,5 & 231175 \\
\hline 2016 & 3,02 & 3601,98 & 13436 & 4,75 & 279334,83 \\
\hline 2017 & 3,61 & 3877,29 & 13548 & 4,25 & 334887,63 \\
\hline 2018 & 3,13 & 3932,21 & 14481 & 6 & 371828 \\
\hline
\end{tabular}

Menurut tabel 1, nilai inflasi mengalami fluktuasi, GDP selalu mengalami penurunan, nilai tukar mengalami kenaikan, suku bunga mengalami fluktuasi namun cenderung meningkat, dan dana pihak ketiga terus mengalami kenaikan. Secara sekilas dapat ditarik kesimpulan hubungan antara GDP dan dana pihak ketiga memiliki hubungan negatif karena ketika GDP turun dana pihak ketiga tetap mengalami kenaikan. Sedangkan hubungan nilai tukar dan suku bunga dengan dana pihak ketiga positif karena ketika kedua variabel itu naik maka dana pihak ketiga pun mengalami kenaikan.

Pendapatan nasional nilai barang dan jasa yang diproduksikan dalam suatu negara pada suatu tahun tertentu dan secara konseptual nilai tersebut dinamakan Produk Domestik Bruto (PDB) secara statistik menunjukkan pendapatan nasional dari sembilan sektor. Perubahan pendapatan sektor-sektor tersebut mempengaruhi masyarakat,baik perseorangan maupun koperasi, sehingga akan mempengaruhi besaran investasi dan tabungan masyarakat. Sejalan dengan penelitian yang dilakukan oleh Afandy (2011) yang menyatakan PDRB riil berpengaruh positif dan signifikan terhadap tabungan masyarakat, pendapat ini didukung oleh penelitian yang dilakukan oleh Sultana and Anwar (2010), Anthony (2012) dan Hendra (2012). Menurut Mankiw (2003) produk domestik bruto adalah nilai pasar dari semua barang dan jasa akhir yang diproduksi dalam suatu 
negara pada periode tertentu. Peningkatan produk domestik bruto ini tercermin dari peningkatan pendapatan masyarakat. Peningkatan pendapatan ini akan memiliki pengaruh terhadap kemampuan masyarakat untuk menabung. sehingga peningkatan pendapatan akan berpengaruh pada DPK bank syariah. Hal ini didukung oleh penelitian yang dilakukan oleh Yusof dan Rodney (2005) yang menyatakan PDB memiliki pengaruh terhadap dana pihak ketiga bank syariah di Malaysia.

Selain itu penelitian yang dilakukan oleh Anthony (2012), Chaturvedi et al. (2009), Sultana and Anwar (2010) menyatakan bahwa adanya hubungan yang negatif antara tabungan nasional dan tingkat inflasi, berbeda dengan penelitian yang dilakukan oleh Hendra (2012) yang menyatakan bahwa tingkat inflasi mempunyai pengaruh positif terhadap jumlah simpanan masyarakat (DPK). Pariyo (Pariyo 2004) melakukan analisis tentang pengaruh variabel makroekonomi yang terdiri atas: 1) SBI, 2) Valuta Asing (USD) dan 3) SWBI terhadap dana pihak ketiga. Hasil yang diperoleh menunjukkan bahwa semua variabel independen berpengaruh secara signifikan terhadap variabel dependen (DPK)

Penghimpunan dana pihak ketiga yang dilakukan oleh bank syariah juga dipengaruhi oleh beberapa variabel makro, seperti inflasi, jumlah uang beredar (M2), dan produk domestik bruto (Haron dan Azmi, 2008). Inflasi dapat diartikan sebagai kenaikan harga secara terus menerus dari barang-barang dan jasa secara umum. Ketika terjadi inflasi, maka akan terjadi ketidakpastian kondisi ekonomi suatu negara yang mengakibatkan masyarakat lebih menggunakan uang mereka untuk konsumsi. Tingginya harga dan tidak diikuti dengan kenaikan pendapatan membuat masyarakat tidak mempunyai kelebihan dana untuk disimpan dalam bentuk tabungan atau diinvestasikan. Pernyataan ini didukung oleh penelitian yang dilakukan oleh Muhammad Abduh dkk (2011) yang menyebutkan bahwa inflasi memiliki pengaruh terhadap deposito bank syariah di Malaysia.

Berdasarkan pemaparan di atas, penelitian-penelitian sebelumnya membahas tentang adanya pengaruh variabel-variabel makroekonomi yang mempengaruhi dana pihak ketiga bank umum syariah di Indonesia, dengan menambahkan beberapa variabel makroekonomi yang baru dan memperbaharui penelitian sebelumnya. Rumusan masalah dalam penelitian ini adalah bagaimana pengaruh variabel tingkat inflasi, nilai tukar, suku bunga, dan GDP terhadap dana pihak ketiga bank umum Syariah? Maka tujuan dari makalah ini adalah untuk mengetahui pengaruh tingkat inflasi, nilai tukar, suku bunga, dan GDP terhadap dana pihak ketiga bank umum Syariah. Dan diharapkan nantinya penelitian ini menjadi acuan bagi perbankan umum syariah dalam menarik dana pihak ketiga dari masyarakat.

\section{Literatur Review}

Menurut Kasmir (2012), dana pihak ketiga adalah kegiatan bank sebagai lembaga keuangan yaitu menghimpun dana dari masyaakat, menyalurkan dana ke masyarakat, dan jasa-jasa lainya. Dana pihak ketiga merupakan sumber dana terpenting bagi kegiatan operasi suatau bank dan merupakan ukuran keberhasilan bank jika mampu membiayai kegiatan operasioanlnya dari sumber dana ini.

Karim (2010) menyatakan bahwa secara umum inflasi berarti kenaikan tingkat harga secara umum dari barang/komoditas dan jasa selama suatu periode waktu tertentu. Inflasi dapat dianggap sebagai fenomena moneter karena terjadinya penurunan nilai unit perhitungan moneter terhadap suatu komoditas. 
Kurs adalah jumlah mata uang domestik yang dibutuhkan unntuk memperoleh unit mata uang asing. Nilai tukar antara kedua negara ditentukan oleh besar kecilnya perbandingan komposisi barang dan jasa yang ada diantara kedua negara tersebut. Nilai tukar atau kurs menunjukkan harga atau nilai mata uang suatu negara dinyatakan dalam nilai mata uang lain (Sukirno, 2006).

Tandelilin (2010) produk domestik bruto (PDB) adalah nilai pasar semua barang dan jasa akhir yang diproduksi dalam perekonomian selama kurun waktu tertentu. PDB merupakan cerminan perekonomian suatu negara. Anna (2012) mengatakan bahwa suku bunga merupakan tingkat yang dibayarkan atau beban atas penggunaan dana atau dengan kata lain biaya pinjaman.

\section{Hubungan Variabel Makroekonomi terhadap Dana Pihak Ketiga}

Bila inflasi naik, maka akan terjadi kenaikan pada harga nominal barang dan jasa. Hal ini menyebabkan daya beli masyarakat akan mengalami penurunan. Pendapatan yang semula dialokasikan sebagai saving akan digunakan sebagian atau seluruhnya untuk kepentingan konsumsi. Karena berkurangnya dana saving secara agregat, bank akan kesulitan dalam mendapatkan dana pihak ketiga.

Bila inflasi turun, maka harga barang dan jasa secara nominal akan mengalami penurunan. Hal ini menyebabkan daya beli masyarakat cenderung mengalami kenaikan. Pendapatan yang semula dialokasikan sebagai konsumsi akan dapat disisihkan sebagai saving. Karena meningkatnya dana saving secara agregat, bank akan lebih mudah dalam mendapatkan dana pihak ketiga.

Bila kurs naik, maka jika suatu mata uang menguat terhadap mata uang negara lain, sehingga barang produksi atau jasa yang dihasilkan negara itu akan menjadi lebih mahal bila dihitung dengan mata uang negara lain tersebut. Akibatnya permintaan terhadap barang atau jasa diharapkan akan mengalami penurunan dan tidak tertutup kemungkinan adanya penggunaan subtitusi yang pada akhirnya akan semakin menekan permintaan. Permintaan yang menurun akan disikapi oleh produsen dengan menurunkan pasokan sehingga tercapai keseimbangan baru.

Pengurangan pasokan dilakukan dengan mengurangi produksi. Bila produksi mengalami penurunan, masyarakat selaku penerima balas jasa faktor produksi dan perusahaan selaku produsen akan mengalami penurunan pendapatan. Akibatnya dana yang tersedia untuk diinvestasikan dan disimpan akan berkurang. Hal tersebut mengakibatkan bank akan kesulitan dalam melakukan penghimpunan dana pihak ketiga.

Bila kurs turun, maka jika suatu mata uang melemah terhadap mata uang negara lain, sehingga barang produksi atau jasa yang dihasilkan negara itu akan menjadi relatif lebih murah bila dihitung dengan mata uang negara lainnya tersebut. Akibatnya permintaan terhadap barang atau jasa diharapkan akan mengalami kenaikan. Permintaan yang naik akan disikapi oleh produsen dengan meningkatkan pasokan sehingga tercapai keseimbangan baru. Penambahan pasokan dilakukan dengan meningkatkan produksi sehingga ekonomi mengalami percepatan.

Bila GDP naik, maka hal ini menggambarkan kegiatan produksi dalam negeri yang meningkat. Pada kondisi tersebut masyarakat sebagai pemilik faktor produksi secara agregat akan memperoleh pendapatan yang lebih besar; baik karena peningkatan pendapatan maupun karena perluasan penerima pendapatan. Akibatnya akan semakin banyak dana yang dapat dialokasikan untuk simpanan (saving). Hal ini akan membuat bank lebih mudah menjaring dana masyarakat sehingga dana pihak ketiganya akan mengalami kenaikan. 
Bila GDP turun, maka hal ini menggambarkan kegiatan produksi dalam negeri yang mengalami perlambatan. Pada kondisi tersebut masyarakat sebagai pemilik faktor produksi secara agregat akan memperoleh pendapatan yang lebih kecil; baik karena menurunnya pendapatan maupun karena berkurangnya jumlah penerimaan pendapatan. Akibatnya dana yang dapat dialokasikan untuk simpanan (saving) akan mengalami penurunan juga. Hal ini akan membuat bank kesulitan dalam menjaring dana masyarakat sehingga dana pihak ketiganya akan mengalami penurunan.

Syafri (2009), melakukan penelitian yang bertujuan untuk mengetahui faktor-faktor yang mempengaruhi tabungan di bank umum. Analisis dilakukan dengan menggunakan uji akar unit dan kointegrasi. Hasil yang diperoleh yaitu semua variabel bebas pendapatan rill, tingkat bunga rill, nilai tukar rill, jumlah cabang bank umum berpengaruh positif dan signifikan terhadap tabungan masyarakat di perbankan.

David (2008), melakukan penelitian yang bertujuan untuk mengetahui variabel mana yang lebih dominan dalam mempengaruhi jumlah dana pihak ketiga (DPK) di bank umum. Variabel yang digunakan antara lain inflasi, pendapatan perkapita dan ekspor. Analisis dilakukan dengan menggunakan regresi berganda. Dari hasil yang diperoleh menunjukkan bahwa tingkat inflasi berpengaruh negatif terhadap usaha penghimpunan dana pihak ketiga pada Bank Umum. Dimana apabila inflasi tinggi, maka penghimpunan dana pihak ketiga pada bank umum akan mengalami penurunan. Dan sebaliknya, apabila inflasi turun, maka penghimpunan dana pihak ketiga pada bank umum akan mengalami kenaikan.

Berdasarkan pemaparan di atas, maka hipotesis dalam penelitian ini adalah sebagai berikut:

$\mathrm{H} 1$ : Inflasi berpengaruh signifikan dan negatif terhadap dana pihak ketiga.

H2 : Nilai Tukar berpengaruh signifikan dan positif terhadap dana pihak ketiga.

H3 : Suku bunga berpengaruh signifikan dan positif terhadap dana pihak ketiga.

H4 : GDP per kapita berpengaruh signifikan dan positif terhdap dana pihak ketiga.

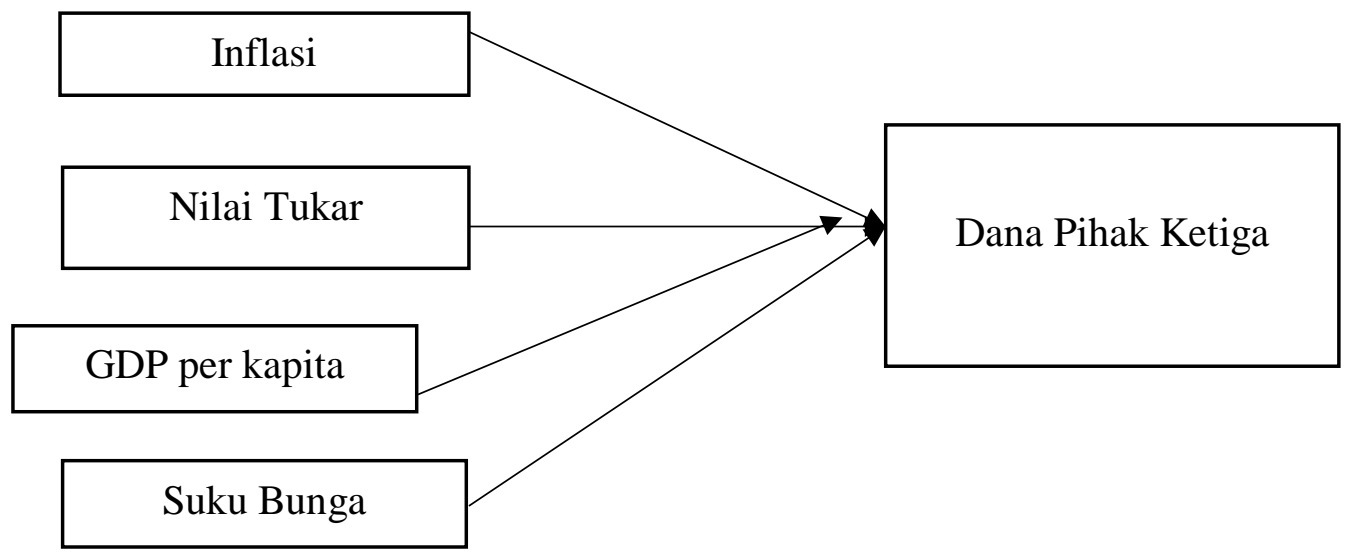

Gambar 1 Kerangka Penelitian

\section{METODE PENELITIAN}

Penelitian ini menggunakan metode penelitian kuantitatif. Sumber data yang digunakan yaitu data inflasi dan nilai tukar yang diambil dari laman resmi Bank Indonesia (BI), data Suku Bunga dari Kementrian Perdagangan (Kemendag), dan data GDP dari id.investing.com, jenis data dalam penelitian ini adalah data panel. Teknik analisis data Ordinary Least Square (OLS) dengan metode regresi linier dalam bentuk data time series selama 5 tahun dari bulan Januari 2014 sampai dengan Desember 2018. Pengolahan data menggunakan Eviews 9. Variabel independen dari penelitian ini yaitu nilai tukar, tingkat suku bunga, inflasi, dan harga minyak 
dunia. sedangkan variabel dependennya adalah investasi Asuransi Syariah yang datanya diambil dari laman resmi OJK. Model penelitian ini adalah;

$$
\mathrm{Y}=\alpha+\beta \mathrm{X} 1+\beta \mathrm{X} 2+\beta \mathrm{X} 3+\beta \mathrm{X} 4+\varepsilon
$$
Y: Dana Pihak Ketiga
$\alpha$ : Konstanta
$\beta$ : Koefisien
$\mathrm{X} 1$ : Inflasi
X2: Nilai tukar
$\mathrm{X} 3$ : Suku bunga
X4: GDP per kapita
$\varepsilon$ : Standar error

Tabel 2 Definisi Operasional Variabel

\begin{tabular}{|c|c|}
\hline Variabel & Definisi \\
\hline Dana Pihak Ketiga & $\begin{array}{l}\text { Dana Pihak Ketiga adalah dana yang diperoleh } \\
\text { dari masyarakat, dalam arti masyarakat sebagai } \\
\text { individu, perusahaan, pemerintah, rumah } \\
\text { tangga, koperasi, yayasan, dan lain-lain baik } \\
\text { dalam mata uang rupiah maupun dalam valuta } \\
\text { asing. (Umiyati dan Leni, 2017) }\end{array}$ \\
\hline Nilai tukar & $\begin{array}{l}\text { Nilai tukar rupiah adalah harga mata uang } \\
\text { suatu negara terhadap mata uang Negara lain } \\
\text { (Pilbeam, 2006). }\end{array}$ \\
\hline Inflasi & $\begin{array}{l}\text { Inflasi adalah kenaikan harga-harga yang } \\
\text { terjadi secara umum,tingkat inflasi merupakan } \\
\text { peningkatan harga-harga sebagai wujud } \\
\text { peristiwa tertentu yang terjadi di luar kendali } \\
\text { pemerintah (Sukirno, 2006). }\end{array}$ \\
\hline Suku bunga & $\begin{array}{l}\text { Suku Bunga Bank Indonesia atau SBI (BI } \\
\text { Rate) adalah suku bunga kebijakan yang } \\
\text { mencerminkan sikap kebijaksanaan moneter } \\
\text { yang ditetapkan oleh Bank Indonesia dan } \\
\text { diumumkan kepada publik. }\end{array}$ \\
\hline GDP per kapita & $\begin{array}{l}\text { GDP adalah "jumlah produk berupa barang } \\
\text { dan jasa yang dihasilkan oleh unit-unit } \\
\text { produksi di suatu negara dalam satu tahun" } \\
\text { (Rosyidi, 2011). }\end{array}$ \\
\hline
\end{tabular}

\section{HASIL DAN PEMBAHASAN}

Penelitian ini menggunakan uji Chow dan uji Hausman untuk pemilihan model yang paling akurat dan yang paling baik diantara pooled least square (PLS), fixed effect model (FEM), dan random effect model (REM).

\section{Uji Chow}

Uji Chow diterapkan untuk memilih antara model ordinary least square $(O L S)$ dengan variabel dummy atau fixed effect. Apabila nilai signifikan dibawah angka probabilitas 0,05 maka dapat ditarik kesimpulan model regresi data panel dengan fixed effect model lebih baik. 
Tabel 3 Hasil Uji Chow

Sumber : Data diolah

\begin{tabular}{lrrr}
\hline Effects Test & Statistic & d.f. & Prob. \\
\hline Cross-section F & 214.203557 & $(5,20)$ & 0.0000 \\
Cross-section Chi-square & 119.974020 & 5 & 0.0000 \\
\hline
\end{tabular}

Berdasarkan Tabel 3 di atas, hasil uji yang disajikan dalam bentuk test cross section fixed effect dengan memperhatikan nilai probabilitas dari 0,05, maka model teknik regresi data panel dengan data panel dengan menggunakan fix effect model tepat diterapkan untuk memprediksikan variabel dependen.

\section{Uji Hausman}

Uji Hausman digunakan untuk memilih antara model fixed effect model atau random effect model. Apabila angka signifikan kurang dari nilai profitabilitas 0,05 maka model regresi data panel lebih cocok menggunakan fixed effect model. Sebaliknya, apabila angka signifikan lebih dari nilai profitabilitas 0,05 maka model regresi data panel lebih cocok menggunakan random effect model.

Tabel 4 Hasil Uji Hausman

Sumber : Data diolah

\begin{tabular}{cccc}
\hline Test Summary & Chi-Square Statistic & Chi d.f. & Prob. \\
\hline Cross-section Random & 0,00000 & 4 & 1,0000 \\
\hline
\end{tabular}

Berdasarkan Tabel 4, Hasil uji Hausman yang disajikan menunjukan probabilitas cross section random lebih besar dari 0,05 maka dapat disimpulkan bahwa model yang tepat adala random effect model.

\section{Uji F}

Uji F dilakukan untuk mencari tahu pengaruh variabel independen terhadap variabel dependen secara bersama-sama atau simultan.

Tabel 5 Hasil Uji F

Sumber : Data diolah

\begin{tabular}{lll}
\hline Variabel Dependen & Probabilitas & Kesimpulan \\
\hline Dana Pihak Ketiga & 0,0002 & Signifikan \\
\hline
\end{tabular}

Berdasarkan tabel 5, menunjukkan bahwa nilai probabilitas 0,0002 lebih kecil daripada 0,05. Maka hasil tersebut memperlihatkan variabel independen berupa inflasi, nilai tukar, suku bunga, dan GDP memiliki pengaruh signifikan terhadap variabel dependen yaitu dana pihak ketiga secara simultan.

\section{Uji T}

Uji t diterapkan untuk mengetahui pengaruh masing-masing variabel independen secara parsial.

Tabel 6 Hasil Uji T

Sumber : Data diolah

\begin{tabular}{ccccc}
\hline Variabel & Koefisien & T-statistic & Prob & Kesimpulan \\
\hline $\mathrm{C}$ & 35,07179 & 7,361230 & 0,0000 & \\
\hline Inflasi (X1) & 0,097633 & 1,978409 & $0,0590^{*}$ & Signifikan \\
\hline Nilai Tukar (X2) & 0,000160 & 3,335737 & $0,0027 * * *$ & Signifikan \\
\hline
\end{tabular}




\begin{tabular}{cllll}
\hline Suku Bunga (X3) & $-0,224311$ & $-2,030709$ & $0,0530^{*}$ & Signifikan \\
\hline GDP (X4) & $-0,001865$ & $-1,733135$ & $0,0954^{*}$ & Signifikan \\
\hline
\end{tabular}

Berdasarkan Tabel 6, hasil uji t menunjukan sebuah model regresi sebagai berikut : $\mathrm{Y}=35,07179+0,097633 \mathrm{X} 1+0,000160 \mathrm{X} 2-0,224311 \mathrm{X} 3-0,001865 \mathrm{X} 4+\mathrm{e}$

\section{Uji Goodness of Fit Model}

Uji goodness of fit model diterapkan untuk mencari tahu seberapa pengaruh variabel-variabel dependen.

$$
\text { Tabel } 7 \text { Hasil Uji Goodness of Fit Model }
$$

Sumber : Data diolah

\begin{tabular}{cc}
\hline$R$-Square & Adjusted $R$-Square \\
\hline 0,707421 & 0,660609 \\
\hline
\end{tabular}

Berdasarkan Tabel 7, didapatkan nilai adjusted r-square sebesar 0,660609 yang berarti dari keempat faktor makroekonomi mempengaruhi dana pihak ketiga bank umum Syariah sebesar $66,0609 \%$ sedangkan 33,9391\% dipengaruhi oleh variabel lainnya yang tidak diteliti dalam penelitian ini.

\section{Analisis Pengaruh Inflasi terhadap Dana Pihak Ketiga}

Berdasarkan hasil pada Tabel 6 variabel inflasi menunjukan hasil yang signifikan secara statistik dengan nilai signifikan $0.0590<0.1$. Sedangkan nilai koefisien variabel inflasi adalah 0,097633 menunjukan berpengaruh positif terhadap dana pihak ketiga bank umum Syariah. Hasil penelitian ini sejalan dengan penelitian yang dilakukan oleh Hendra (2012) yang menyatakan bahwa tingkat inflasi mempunyai pengaruh positif terhadap jumlah simpanan masyarakat (DPK). Berbeda dengan Anthony (2012), Chaturvedi et al. (2009), Sultana and Anwar (2010) menyatakan bahwa adanya hubungan yang negatif antara tabungan nasional dan tingkat inflasi. Hal ini terjadi karena ketika inflasi naik maka akan terjadi kenaikan pada harga barang dan jasa. Ini dapat menyebabkan daya beli masyarakat berkurang. Dan pendapatan yang semuladi alokasikan untuk menabung menjadi dialokasikan untuk kepentingan konsumsi. Maka bank akan kesulitan dalam mendapatkan dana pihak ketiga.

\section{Analisis Pengaruh Nilai Tukar terhadap Dana Pihak Ketiga}

Berdasarkan hasil pada Tabel 6 variabel nilai tukar menunjukan hasil yang signifikan secara statistik dengan nilai signifikan $0.0027<0.1$. Sedangkan nilai koefisien variabel inflasi adalah 0,000160 menunjukan berpengaruh positif terhadap dana pihak ketiga bank umum Syariah. Hasil penelitian tidak sejalan dengan hasil penelitian Fitria Sanusi (2008) yang menunjukkan bahwa kurs berpengaruh negatif dan signifikan terhadap DPK Pada Perbankan Syariah Periode 20002007. Hal ini mungkin terjadi karena ketika nilai tukar mengalami kenaikan maka harga-harga barang impor pun mengalami kenaikan. Masyarakat pun lebih memilih menyimpan uangnya daripada membelanjakan uangnya yang membuat perbankan mudah dalam mendapatkan dana pihak ketiga.

\section{Analisis Pengaruh Suku Bunga terhadap Dana Pihak Ketiga}

Berdasarkan hasil pada Tabel 6 variabel suku bunga menunjukan hasil yang signifikan secara statistik dengan nilai signifikan $0.0530<0.1$. Sedangkan nilai koefisien variabel inflasi adalah 0,224311 menunjukan berpengaruh negatif terhadap dana pihak ketiga bank umum Syariah. Hal ini sama dengan yang dikemukakan Sutono dan Batista (2013) yang menunjukan bahwa suku bunga berpengaruh signifikan terhadap dana pihak ketiga. 


\section{Analisis Pengaruh GDP per Kapita terhadap Dana Pihak Ketiga}

Berdasarkan hasil pada Tabel 6 variabel GDP per kapita menunjukan hasil yang signifikan secara statistik dengan nilai signifikan $0.0954<0$. . Sedangkan nilai koefisien variabel inflasi adalah -0,001865 menunjukan berpengaruh negatif terhadap dana pihak ketiga bank umum Syariah. Hal ini didukung oleh penelitian yang dilakukan oleh Yusof dan Rodney (2005) yang menyatakan PDB memiliki pengaruh terhadap dana pihak ketiga bank syariah di Malaysia. Hal ini terjadi mungkin dikarenakan ditengah pendapatan yang turun masyarakat lebih memilih menahan konsumsi dan lebih memilih berinvestasi. Namun, dalam investasinya masyarakat memilih yang tidak terlalu beresiko yakni di sektor perbankan. Maka bank akan lebih mudah menarik dana dan pada akhirnya dana pihak ketiga meningkat.

\section{KESIMPULAN DAN SARAN}

Variabel nilai tukar, inflasi, suku bunga, dan GDP per kapita memiliki pengaruh yang signifikan terhadap dana pihak ketiga bank umum Syariah. Variabel inflasi dan nilai tukar memiliki pengaruh positif sedangkan variabel suku bunga dan GDP per kapita memiliki pengaruh negatif pada dana pihak ketiga bank umum Syariah. Hasil penelitian ini memiliki implikasi bagi para pelaku usaha perbankan untuk menentukan waktu yang tepat dalam menarik dan menyalurkan dana pihak ketiga dari masyarakat. Dan dapat menjadi acuan untuk mengeluarkan kebijakan terkait bisnisnya. Dan bagi peneliti selanjutnya dapat menjadi acuan untuk mengembangkan kembali penelitian berikutnya. Pada penelitian selanjutnya diharapkan dapat menambah variabelvariabel terkait lainnya selain variabel yang telah diteliti dalam penelitian ini.

\section{Ucapan Terimakasih}

Dengan selesainya penelitian ini, saya mengucapkan terimakasih pada Allah SWT yang telah memberi kesempatan saya dapat menyelesaikan penelitian ini. Kemudian saya mengucapkan terimakasih pada orang tua saya yang selalu mendukung dalam proses penyelesaian penelitian ini. Dan saya mengucapkan terimakasih pada seluruh pihak Universitas Airlangga yang memfasiliasi saya dalam menyelesaikan penelitian ini.

\section{REFERENSI}

Anna, Chingarande. 2012. The impact of interest rates on foreign direct investment: A case study of the Zimbabwean economy (February 2009-June 2011). International Journal of Management Sciences and Business Research, 1(5): 1-24.

Anthony, Orji. 2012. Bank Savings and Bank Credit in Nigeria : Determinants and Impact on Economics Growth. International Journal of Economics and Financial Issues. Vol.2 No.3. pp.357-372.

Arifin, Zainul. 2009. Dasar-dasar Manajemen Bank Syariah. Jakarta: Raja Grafindo Persada.

Chaturvedi, Vaibhav., Brajesh Kumar dan Ravindra H. Dholakia. 2009. Interrelationship Between Economic Growth, Savings and Inflation in Asia. Journal Of International Economics Studies. Vol.- No.23. pp. 1-22.

Danupranata, Gita 2013. Buku Ajar Manajemen Perbankan Syariah, Yogyakarta: Salemba Empat.

David, Ahmad. 2008. “Analisis Faktor-Faktor Yang Mempengaruhi Penghimpunan Dana Pihak Ketiga Pada Bank Umum di Sumatera Utara”. Jurnal Ekonomi Moneter dan Perbankan, Universitas Sumatera Utara.

Fitria Sanusi. Faktor-Faktor Yang Mempengaruhi Penghimpunan Dana Masyarakat Pada Perbankan Syariah Periode 2000-2007. Tesis. Lampung : Pascasarjana - Universitas Lampung

Hasibuan, Malayu S.P. 2011. Dasar-dasar perbankan. Bumi Aksara. Jakarta. 
Kasmir. 2012. Dasar-Dasar Perbankan. Jakarta: PT. Raja Grafindo Persada.

Kuncoro, Mudrajad dan Suhardjono. 2002. Manajemen Perbankan Teori dan Aplikasi. Yogyakarta: BPFE Yogyakarta.

Mankiw, N. Gregory. 2003. Pengantar Ekonomi Makro. Edisi 3. Terjemahan oleh Chriswan Sungkono. Jakarta: Salemba Empat.

Pariyo. 2004. "Variabel Makroekonomi Yang Mempengaruhi Penghimpunan Dana Pihak Ketiga (Studi Kasus Bank Muamalat Indonesia Periode 2000-2003).” Disertasi, Program Studi Timur Tengah dan Islam, Universitas Indonesia.

Pilbeam, Keith. (2006). International Finance 3rd Edition. New York.

Rosyidi, Suherman. 2011. Pengantar Teori Ekonomi: Pendekatan kepada Teori Ekonomi Mikro dan Makro. Jakarta: Raja Grafindo Persada.

Sultana, Samar and Anwar Ali Shah G. Syed. 2010. Macroeconomic Determinants of Savings and Investment in Pakistan. Journal of Business Strategies. Vol. 4 No. 2. pp. 28-42.

Syafri. 2009. "Analisis Faktor-Faktor Yang Mempengaruhi Tabungan Masyarakat Pada Bank Umum". Jurnal Ekonomi Moneter dan Perbankan, Universitas Trisakti.

Tandelilin, E. 2010. Portofolio dan Investasi Teori dan Aplikasi. Edisi pertama. Yogyakarta : Kanisius.

Umiyati dan Leni. 2017. "Faktor-faktor yang mempeengaruhi pembiayaaan pada Bank Umum Syariah devisa di Indonesia". Jurnal ekonomi dan Perbankan Syariah, Vol.5 (1): 39-61.

Yusoff, Remali and Rodney Wilson. 2005. An Econometric Analysis of Conventional and Islamic Bank Deposits In Malaysia. Journal Riview of Islamic Economics,Vol. 9 No. 1. 